\title{
OCTAVIAN'S FOOTPRINTS: HILLFORTS, CAMPS AND ROADS BETWEEN BURNUM AND SINOTIUM
}

\author{
Silvia Bekavac \\ Sveučilište u Zadru \\ Odjel za arheologiju \\ Odjel za povijest umjetnosti \\ Obala kralja Petra Krešimira IV/2 \\ HR - 23000 Zadar \\ s.bekavac1011@gmail.com
}

\author{
Željko Miletić \\ Sveučilište u Zadru \\ Odjel za arheologiju \\ Obala kralja Petra Krešimira IV/2 \\ HR - 23000 Zadar \\ zmiletic@unizd.hr
}

UDK / UDC: 904:355.716(497.5 Petrovo polje)"652" Izvorni znanstveni rad/Original scientific paper https://doi.org/10.52064/vamz.54.1.8

On the basis of a recent field survey of Petrovo polje, in comparison to the data of Appian and Dio Cassius, the Octavian war campaign against the Dalamatae in the area between Burnum and Sinotion (Synodium, Synodion, Sinotium) is reconsidered. We recognize two temporary Roman military camps. The first, near the village of Parčić, is part of the Octavian contravallation in the northwest corner of Petrovo polje, the siege system by which Dalmatian Promona was surrounded. We conclude that the cen- tral oppidum of that polis integrated three areas on and around the Orišnica hill. On the neighbouring hill, Petrovac, we locate the citadel (acropolis) of Promona. The second camp, above the villages of Otavice and Gradac, located on the southern slope of the Svilaja mountain, we link with the blockade of the Setovia hillforts on the edges of the eastern half of Petrovo polje. The chronological stratification of the Roman road network between Burnum and Salona is considered.

Key words:

Octavian, Promona, contravallation, siege camps, Setovia

During a period of military activity more than a century long in northwest Illyricum, in the process of consolidating Roman rule, first in the protectorate and then in the Province, Petrovo polje (Peter's Field) was the site of the intertwined interests of the three parties: Rome, Liburni and Delmatae (Fig. 1). Promona and Sinotion, two pre-Roman poleis between which the field was divided, were located on a key longitudinal transit route in the continental hinterland linking northern Italy with Macedonia, and had been the object of numerous Roman military expeditions, as well as of Liburno-Dalmatian friction (Fig. 2).

Gaius Sempronius Tuditanus achieved a triumph over the lapodes in $129 \mathrm{BC}$ for the military expedition which he waged against them, the Celtic Taurisci and other peoples in the wider environment of Aquileia. ${ }^{1}$ It was the beginning of Roman inva- sions from the area of Aquileia among the lapodes, Liburni and Dalmatae, peoples in northwest Illyricum. On this occasion the Liburni probably contracted with the Romans as foederati, which is an essential fact for future relations with the third-party Dalmatae.

Modern historiography clearly distinguishes between two different Metelli who were the protagonists of two war episodes. ${ }^{2}$ Morgan, as well as Bilić-Dujmušić, tried to prove that, in the victory over the lapodes and the Segestani of a consul in $119 \mathrm{BC}$ Lucius Aurelius Cotta, some Metellus participates who is not the same person as the consul of 119 BC: Lucius Caecilius Metellus (Delmaticus). He waged war actions on the territory of the hostile Dalmatae for which he obtained the desired triumph in $118 \mathrm{BC} .^{3}$ This contrast between friendly Salonitans and hostile
$1 \quad$ Liv. Periochae 59; App. III. 10; Plin. Nat. 37. 129; Act. Triumph. de lapodibus (129 BC); CIL 1, 652a; CIL 5, 8270; Broughton 1951, 504; Zaninović 1988, 54; Čače 1991, 59-62, 65-67; Šašel Kos 2005, 61-62, 321-322; Chiabà 2017, 172, 179-180; Milivojević 2017, 104-110.
Šašel Kos 2005, 306-311; Milivojević 2017, 99-103.

App. III. 10-11; Liv. Periochae 62; Eutr. 4.23.2; Act. Triumph. de Delmateis (117 BC); Broughton 1951, 525-529; Morgan 1971, 271-292; Bilić-Dujmušić 2004 210-226; Dzino 2005, 63-64; Periša 2015, 176-180. 
FIGURE 1. Polis of Promona, Petrovo polje and Vrba valley are positioned on the natural passing route between Burnum in Liburnia and the Delmatian Salona

(৫) Google Earth; edited by Ž. Miletić, S. Bekavac).

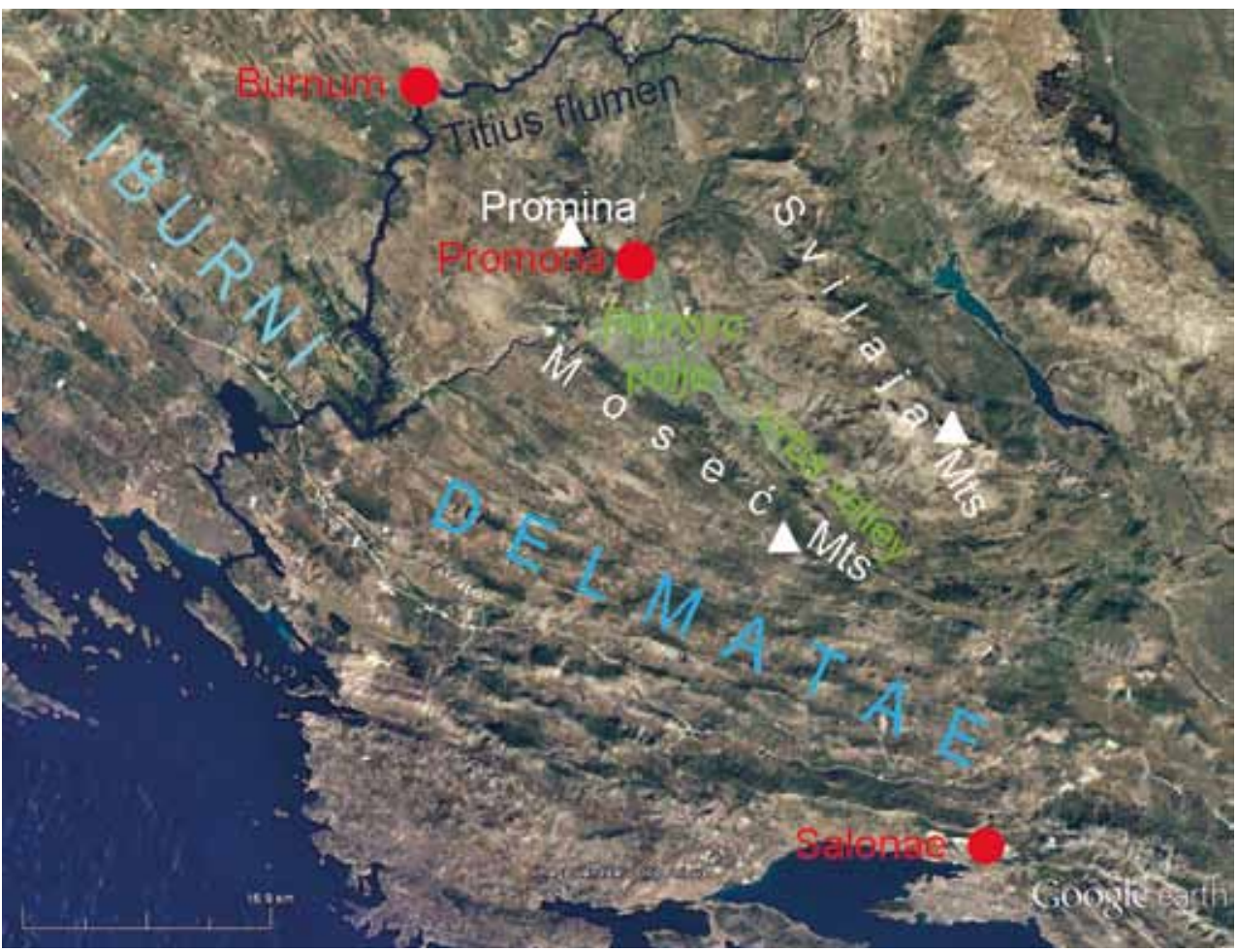

Dalmatae in the environment may be the construction of a tendentious Appian interpretation, but perhaps a real situation in which the multi-ethnic Dalmatian harbour town of Salona was in a kind of allied relationship of consent with Rome. There was no complete military alliance among the Dalmatian communities; only those affected responded with military action.

The activity of proconsul Gaius Cosconius in the Illyrian protectorate is part of a broader Roman effort to restore order in the disturbed provinces after the Social War. The Iapodes and Dalmatae were defeated, and Salona, the future capital of the province, was returned to Roman rule around 78 AD. ${ }^{4}$ BilićDujmušić's remark is important here, based on Eutropius' expression (taken from Livy) "conposito bello", that Cosconius's war was over, which means that the post-war framework (levies, hostages, control of key points) had been arranged. According to him, this arrangement of Illyricum resulted in the absence of war news for two decades, until the time of Pompey. ${ }^{5}$ Zaninović thought Cosconius's march was from Aquileia in northern Italy, across Histria, lapodia and Liburnia. ${ }^{6}$ From the land of the lapodes he could reach Salona with ships sailing along the coast of Liburnia, but this direction of navigation was hampered by fairly strong currents in the opposite direction, flowing along the eastern Adriatic coast from the southeast to the northwest. The communication line through the hinterland of Illyricum was probably already being used at the beginning of the $1^{\text {st }}$ century $B C$, and along this the Romans later built a longitudinal road between Aquileia in Italy and Dyrrachium in Macedonia. Before the Roman army traced these roads, they were already part of the established trade routes through the territory of the lapodes and Liburni. The claim is confirmed by the findings of the aes rude and aes signatum, bronze coins issued by Greeks, Egyptians, Carthaginians and Numidians, and $2^{\text {nd }}$-century Republican aes grave from hoards buried mainly between about 100 and 75 BC.? After passing through Liburnia, this communication crossed the Krka river (Titius flumen) and entered the area of the pre-Roman Promona, the frontier Dalmatian polis. ${ }^{8}$

At the time of Caesar's proconsulship of the newly established province of Illyricum, the Delmatae occupied Promona, a polis and important fortress that the Romans had previously given to the Liburnians (who were probably foederati), as one of the measures of Cosconius's post-war regime in Dalmatia. A strong military force that Caesar sent to that area was destroyed. ${ }^{9}$ Čače advocates that the action was conducted when Caesar was near Illyricum, not during his short visit to Cisalpine Gaul in
4 Eutr. Brev. 6.1.4.; Eutr. Oros. 6.23.1; 29; Bilić-Dujmušić 2004, 233-242; Periša 2015, 178-180; Milivojević 2017, 111-115

$5 \quad$ Eutr. Brev. 6.1.4, “ad Illyricum missus est C. Cosconius pro consule multam partem Dalmatiae subegit, Salonascepit et composito bello Romam post biennium rediit”; Bilić-Dujmušić 2004, 241-242.

$6 \quad$ Zaninović 1988,55

\footnotetext{
$7 \quad$ Mirnik 2009, 483-485.

8 Miletić 2006, 130-131.

9 Promona is twice called Liburnian (see App. III. 12.34, 12.72); Zaninović 1988, 55; Čače 1989, 87; Čače 1993, 5-6; Bilić-Dujmušić 2004, 243-253; Dzino 2005, 82-83; Šašel Kos 2005, 444; Periša 2015, 228-229.
} 


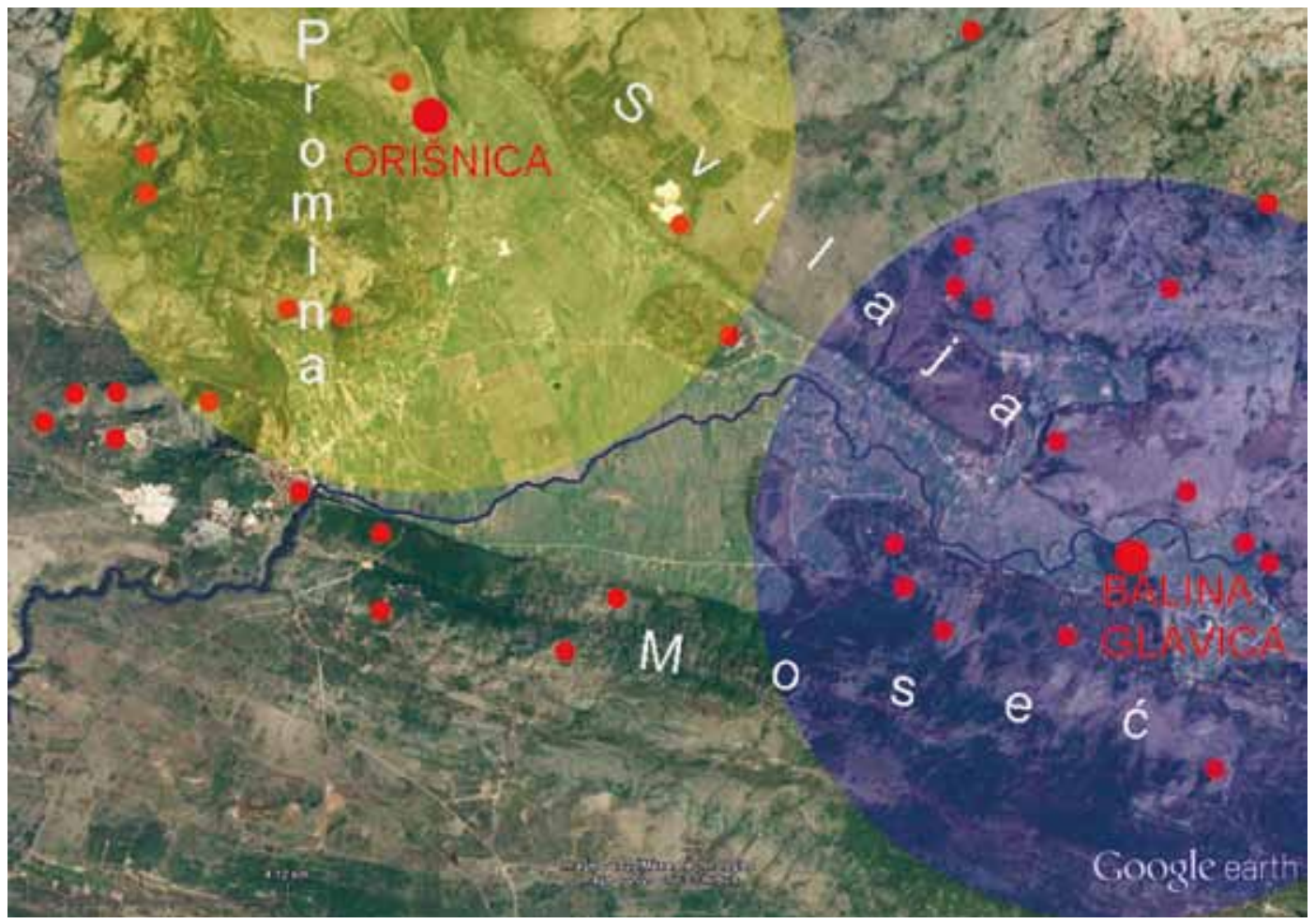

FIGURE 2. The areas of Promona (yellow) and Sinotion (purple) are presented as ideal circles of 100 square kilo metres, centred on the Orišnica hill and Balina glavica, respectively (c Google earth; edited by $S$. Bekavac, Ž. Miletić)

September - October $51 \mathrm{BC}$, but a longer one in the spring and autumn of $50 \mathrm{BC} .{ }^{10}$ Because of the war with Pompey, that defeat had become ephemeral to Caesar. ${ }^{11}$ Caesar completely hid his own failure, which was not insignificant, as can be seen from the fact that this defeat served as an excuse for the subsequent Octavian revenge campaign. ${ }^{12}$ Rome's alliance with the Dalmatae, which we can assume to have been established no later than the era of Cosconius and Caesar's inability to control their own proconsular territory, led to their adherence to Pompey. During the winter of $49-48$ BC, according to Caesar's order, Aulus Gabinius went to Illyricum (depending on interpretations, along the land route around the Adriatic or across the Sea, but not from Brundisium) with fifteen cohorts of recruited soldiers and 3000 horsemen. We do not know what happened to that support. Marasco, then BilićDujmušić and Šašel Kos, convincingly proved that Appian ${ }^{13}$ has compressed that first episode of Gabinius's activity in Illyricum with the second, which occurred after the Battle of Pharsalus, at the turn of the year 48 to $47 \mathrm{BC} .{ }^{14}$ By engaging against the Dalmatae, Gabinius was to assist Quintus Cornificius, who led operations against the Pompeians in southern Illyricum. Gabinius's military operations ended disastrously. Because of the harsh weather, he did not get supplies by sea, was in disarray, and finally suffered a serious defeat by the Dalmatae near the Petrovo polje in the gorge of the Vrba stream. ${ }^{15}$ The circumstances of the disaster and the figures on human losses are reported in Bellum Alexandrinum "over two thousand soldiers, thirty-eight centurions and four tribunes." ${ }^{16}$ Appian describes the same event and states that "the Illyrians ... killed all of Gabinius's army"17, and in another chapter claims the "Dalmatae had killed five cohorts .. and seized the military standards." ${ }^{18}$ Since then, at least, Burnum, on the River Krka (Titius flumen) with the nearby river-sea port of Scardona, and borderline Liburnian communities in the direction of the Delmatae and Promona, had had to become important points for military operations into the Dalmatian area. ${ }^{19}$ The loyalty of the Liburnians was strengthened by the Italics, whose presence, according to Zaninović, can be traced back even to the historical episode with Cinna and Carbo, who intended to prepare in Liburnia for the conflict with Sula in $84 \mathrm{BC} .{ }^{20}$ Remains of a summer camp (castrum aestivum) in Burnum, on the Liburnian side of the River Krka, erected possibly since Caesar's or Octavian's period, may have been recognized as concentric square fossae recently discovered by non-destructive methods in the immediate vicinity of a permanent legionary camp built later, at the very beginning of the $1^{\text {st }}$ century AD. ${ }^{21}$
10 Čače 1993, 5-6; Bilić-Dujmušić 2004, 245-248; Milivojević 2017, 238.

11 App. III. 12; Zaninović 1988, 55.

12 Čače 1993, 9; Milivojević 2017, 242.

13 App. III. 12

$14 \quad$ Wilkes 1969, 41; Marasco 1997, 314-321; Bilić-Dujmušić 2000, 181-189; Šašel Kos 2005, 347-356; Dzino 2005, 90

\author{
B. Alex. 42.4-43.3; App. III. 12; 25; 27; Plu. Ant., 7. Dio. Cass. 42.11. \\ B. Alex. 43.1.-3 \\ App. III. 12 \\ App. III. 25 \\ Zaninović 1968, 122 \\ Zaninović 1988, 54-55
}

Campedelli, Dubbini, Monica 2017, 286; Vrkić 2017, 211-212. 
FIGURE 3. Appian's sharply pointed sawtooth-like hills on the east side of the Promina mountain include Petrovac and Orišnica (made by S. Bekavac, Ž. Miletić).

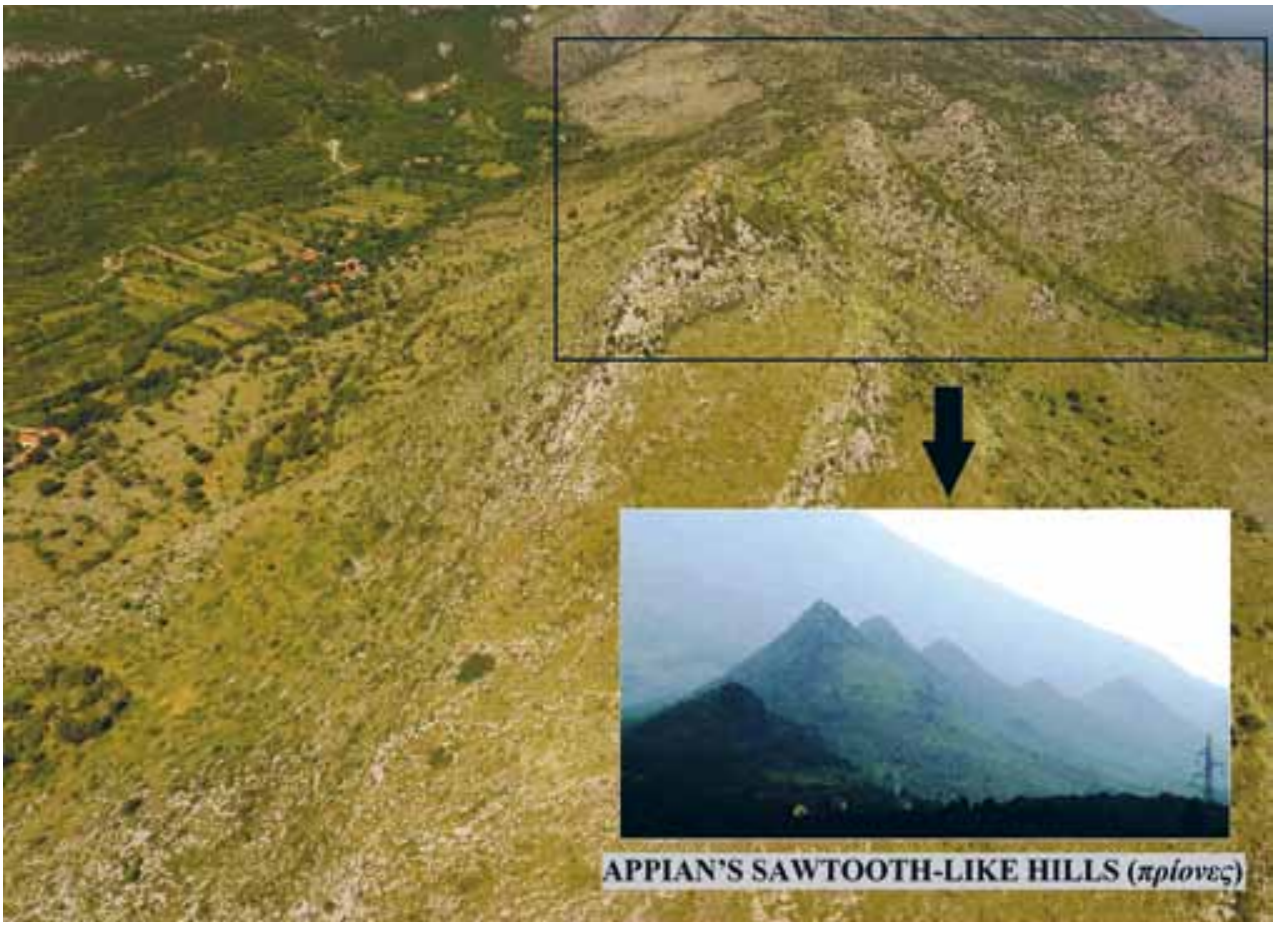

In the period that followed, as Appian says (Illyr. 25), for ten years the Dalmatae did not release a weapon from their hands. ${ }^{22}$ Asinius Pollio celebrated a triumph over the Parthini for victory in the war of $39 \mathrm{BC}$, and Džino and Bilić-Dujmušić prove that, during the same campaign, he defeated the Dalmatae, who occupied Salona, and destroyed the city walls. ${ }^{23}$ During the upcoming conflict with Mark Antony, Octavian could not allow the province of Illyricum under his authority to be overturned. The maritime connection with the eastern Mediterranean via the Adriatic was not reliable, so he tried to secure control of the hinterland and the connection to the east by land, for which he took Siscia (Segesta), a strategic point in Pannonia. ${ }^{24}$ Džino, in contrast, believes that the direct clash between Octavian and Antony was not yet in sight; therefore the Illyrian expedition was not planned in advance, but primarily caused by the threat to Roman interests in the area. ${ }^{25}$ The punishment of the Dalmatae and the winning of the standards they took from Caesar's legate, Aulo Gabinius, served to demonstrate Octavian military virtues and to consolidate his image and position in the Senate..$^{26}$ From Siscia, part of the invasion forces descended towards the coastal area, into the Dalmatian sector. This unsuccessful campaign of Marcus Agrippa, mentioned only by Dio Cassius, was the prelude to Octavian warfare in Petrovo polje and Promona during $34 \mathrm{BC}{ }^{27}$

\section{Promona}

If we apply the calculation from the neighbouring territory of Liburnia, according to which the early-Roman municipalities constituted from native communities held an area about $200-$ 300 square kilometres, and peregrine civitates around $80-100$ square kilometres, then included in the territory of the preRoman town of Promona would be the hillforts southeast and southwest of the Promina mountain and in the western part of Petrovo polje. ${ }^{28}$ In discussion about the placement of a central settlement, the key point is Appian's specific statement that the town of Promona is surrounded by sharply pointed sawtoothlike hills - זpioves (IIlyr.25) - which we can only identify with a line of pointed hills on the east side of the Promina mountain (Fig. 3). Guided by this statement, Veith places the centre of the polis of Promona on an elongated flattened hillock at the northwest edge of Petrovo polje, just below the eastern slopes of those hill-teeth. ${ }^{29}$ The viewpoint of researchers Zaninović, Rašković, Bilić-Dujmušić and Šašel Kos, who then dealt with the issue of Promona's placement more thoroughly, was that the centre of the polis should be located somewhere in the area of the hill of Velika Orišnica, and on the plateau of Mala Orišnica. ${ }^{30}$ Recently, Periša has made a different proposal. ${ }^{31}$ In presenting
22 Čače 1979, 111; Bilić-Dujmušić 2004, 219-226; Džino 2011, 159; Šašel Kos gives an excellent discussion of the period (Šašel Kos 2005, 357-374).

23 Bilić-Dujmušić 2004, 366-378. Džino 2005, 99-101; 2011, 161-165; Šašel Kos 2005, 372-373; Lutton 2012, 138-139.

24 Bilić-Dujmušić 2004, 426-428.

25 Džino 2005, 104-105.

26 Šašel Kos 2005, 461, 465.

27 Dio. Cass. 49.38.3; Bilić-Dujmušić 2004, 430, 430-444, 449-454; Šašel Kos Orišnica: the citadel tower; slopes SE of Mala Orišnica: town); Šašel Kos 2005, 443-444.

31

Periša 2015, 232-235

Miletić 2020, 34-36, fig. 11.

Veith $1914,63-80$.

Zaninović 1992, 36-37; Rašković 2001, 393-396 (Velika Orišnica: fort; 2013, 191. 


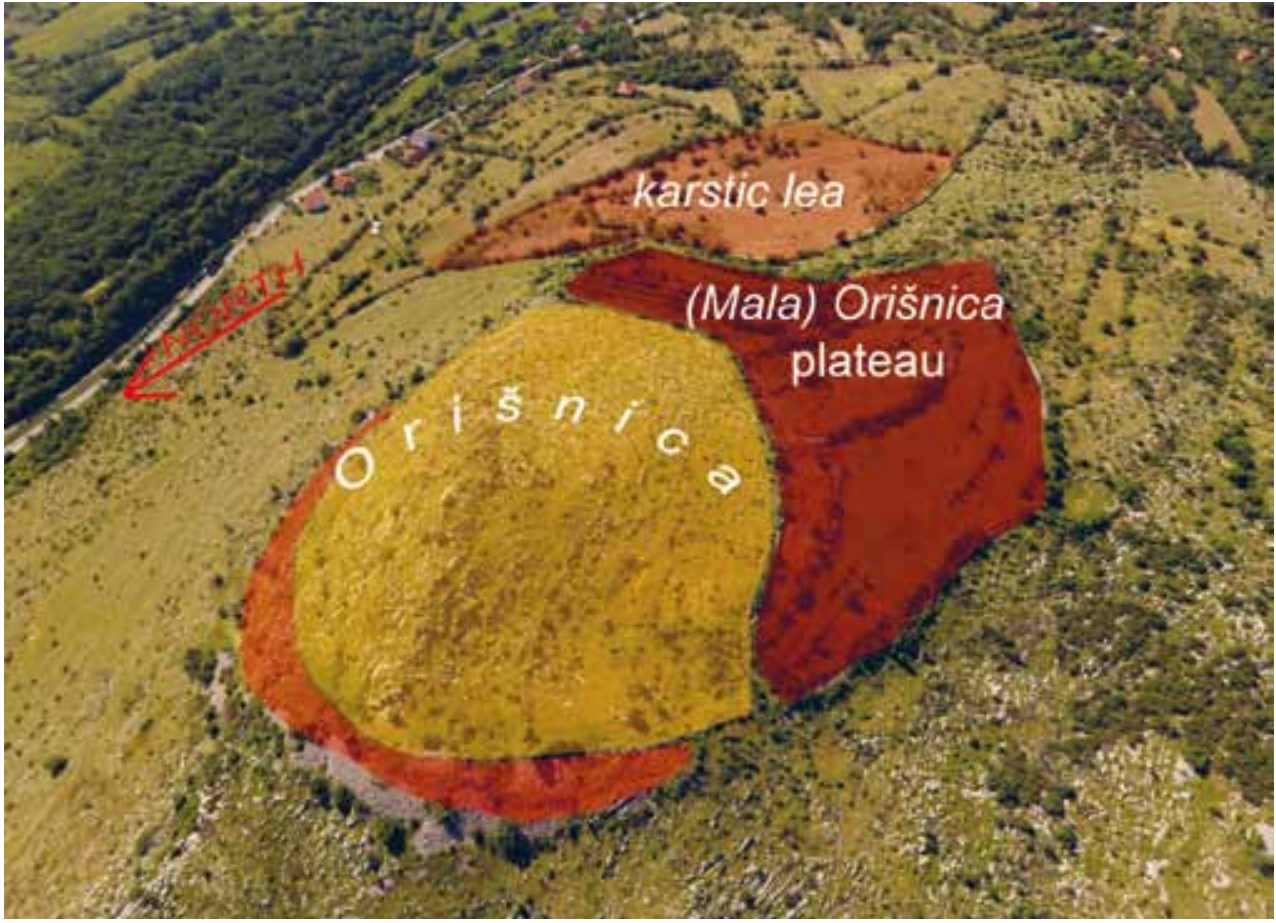

FIGURE 4. The central settlement of the Liburnian polis of Promona integrates three areas: the first part is the (Mala) Orišnica plateau, defined by the remains of the walls; the second is the karstic lea southeast of Mala and Velika Orišnica, and the third is the hill of (Velika) Orišnica (made by Ž Miletić).

his arguments, he relativized the usefulness of Appian's specific allegation, which he felt could be interpreted in other ways than the existing propositions. Therefore, he seeks the stronghold which the Romans conquered on the opposite side, the west, of the Promina mountain, where the hillforts of Gradina, above the village of Kaldrma, and Čuljane and Šušelj, above the village of Lukar, are located. He interprets Appian's citation of the multi-partition of Promona as being an acropolis at the very top of Promona (1 148 metres above sea level) with the suburbs on the plateau southwest of the summit. We agree that the fortifications mentioned are part of the territory of the pre-Roman polis of Promona, but we still claim that the centre of the polis is located on the border of the slopes of the Promina mountain and the northwest edge of Petrovo polje, exactly in the areas of the Orišnica hill and Mala Orišnica plateau, and on the flat slopes east of it (Fig. 4). The main argument is our discovery of the Octavian contravallation in the northwest corner of Petrovo polje.

\section{Three parts of the town of Promona}

Appian's description of the Octavian Campaign mentions the Liburnian polis of Promona, a citadel above the town and the surrounding hills with sentries (IIlyr. 25; 26); we have compared this with the results of field surveying, to conclude that the town within the rampart integrated three areas. The first part is the (Mala) Orišnica plateau, defined by the remains of the walls; the second is the karstic lea southeast of Mala and Velika Orišnica; and the third is the hill of (Velika) Orišnica (Fig. 4). To its north, Velika Orišnica borders the Petrovac hill, where we have located the citadel (acropolis) of Promona known from Appian's description of the siege, now recognized for the first time (Fig. 5).
The part of the town of Promona located on the Mala Orišnica plateau has an approximately trapezoidal shape. It is protected by large, roughly cut stone blocks partially covered by recent stone drywalls, and covers an area of 2 hectares. East of that sector, one cascade (10 to 20 metres) lower, is the second one in the form of an elongated triangle, with an area of approximately 2.6 hectares. On the "Franzisco-Josephinische Landesaufnahme" map (Third Military Survey), drawn between 1869 and 1887, there were still visible stone drywalls erected from the remains of the former ramparts. ${ }^{32}$ The map segment accurately depicts the current situation in the entire area of Mala Orišnica - that is, it corresponds to today's relief configuration of the surface - except that it now lacks a striking line of dry wall 150 metres long, drawn on the map at the eastern edge of the lower town. The Siverić-Knin railway projected in $\mathbf{1 8 7 2}$ was drawn on the relief map at the foot of Orišnica, although construction work began only in 1885 and was completed in $1888 .{ }^{33}$ It can be assumed that the dry walls were built of stones from the remains of the former eastern rampart of Promona and were used as building material for the $19^{\text {th }}$-century railway embankment. On the surface of both parts of the town there are sporadic fragments of ceramics and hand millstones (Fig. 6).

\footnotetext{
32 https://mapire.eu/en/map/thirdsurvey25000/, 30. 11. 2020.

33 Bunijevac 2009, 549-551.
} 
FIGURE 5. To its north, Velika Orišnica borders the Petrovac hill, where we have located the citadel (acropolis) of Promona (made by S. Bekavac, Ž. Miletić).

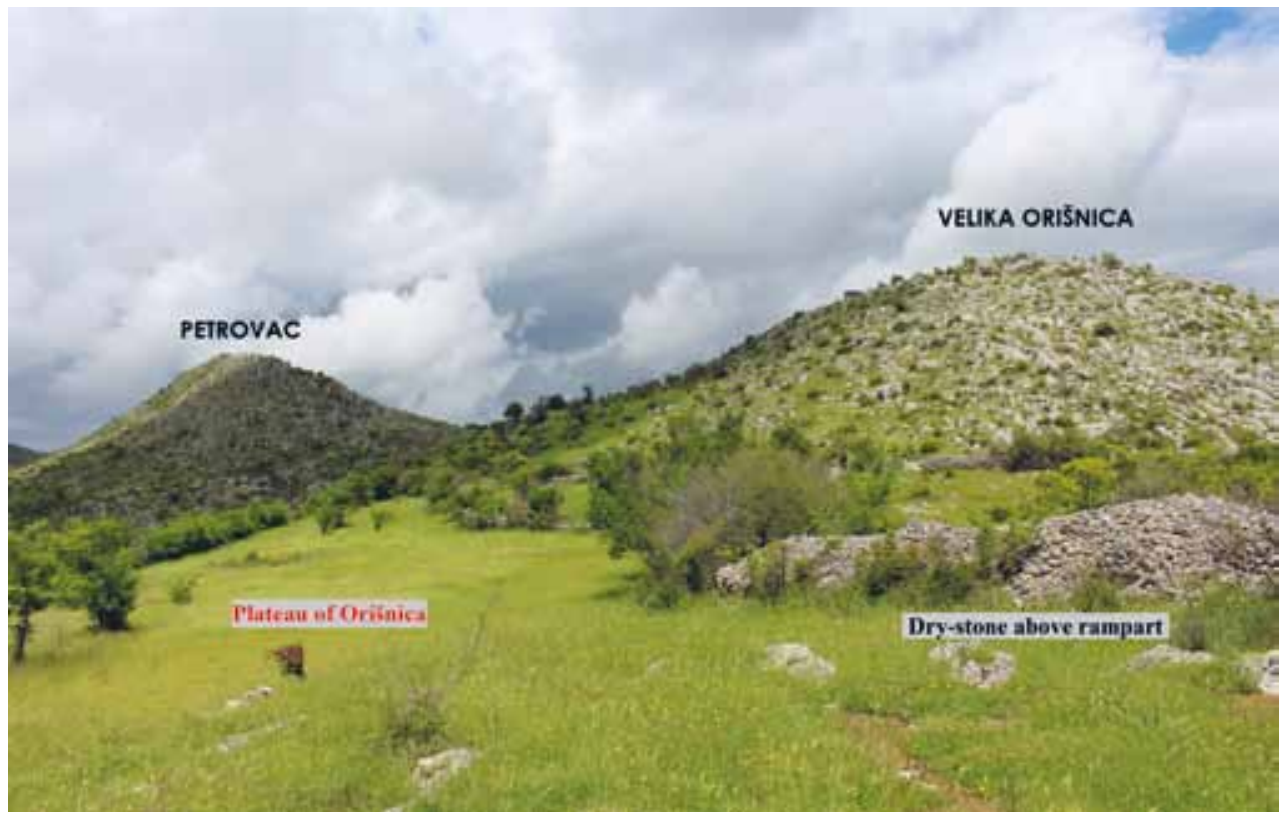

The third part of the town is the karstic hill of Velika Orišnica, with only a small narrow belt, no more than 1000 square metres in area, on the north and northeast sides suitable for edifices or defensive positions, where remains of the collapsed ramparts are seen (Fig. 7). The very rough, rocky remainder of the hill fort could potentially be used for housing sheep and goats, storing supplies, as a natural watchtower and as a corridor for access up to the adjacent citadel on the Petrovac hill. All three parts of the town have a total dimension of about 47000 square metres, to which should be added the surface of the rocky area of the Velika Orišnica hill.

According to Appian, ${ }^{34}$ the majority of the 12000 Dalmatae under the command of Versus were defended in the town, while others were deployed to remote guardposts on mountain peaks of Promina, from which they retreated after the Roman commandos, under cover of darkness, conquered these few prominent positions. ${ }^{35}$ In our reconstruction of the spatial layout of Promona, according to which the citadel should be sought outside the hill of Orišnica, each soldier of Versus had at least 4 square metres of space inside the town, which is several times more than previous authors have suggested. This resolves the problem that was first pointed out by Bilić-Dujmušić: the lack of space in which the soldiers of Versus's army could fit, which made effective defence impossible. ${ }^{36}$ In addition to the people, the space had to be occupied by huge logistical supplies, to withstand the siege they were preparing for. The daily needs of the besieged were: 50 tonnes of food for humans (salted meat, flour) and animals (hay), dozens of tonnes of water, about 100 sheep. ${ }^{37}$

\section{Citadel}

After the Romans broke in to the town of Promona and cut down about one-third of the defenders in street fighting, the remaining 6 to 8 thousand Delmatians withdrew into the acropolis-citadel. ${ }^{38}$ The Delmatians surrendered on the fifth day of the siege after attempting a breakthrough when the Roman cohort on guard fled in panic, which was subsequently punished by decimation. ${ }^{39}$ As a result of several field and aerial surveys, we have pinpointed, for the first time, the remains of the citadel of Promona north of the town, exactly on the neighbouring Petrovac hill, and we have gained basic layout information. The citadel enclosed an approximately square area, measuring about 18000 square metres, with no bedrock exposed on the surface because it had been artificially flattened, unlike other harsh karstic slopes of the hill and bare rough rocks on hills to the north (Fig. 8). The altitude difference of the citadel over a length of 250 metres is about 50 metres, which means that the area was a steep slope, inclining south and east. Although steep terrain is not ideal for the construction of edifices for the permanent residence of inhabitants, it was suitable for a fort. Its advantage was an excellent passive defensive morphology. The long east and west sides of the citadel end in high, steep cliffs. A barely passable saddle north of the citadel divides it from the next hill, Oštraglava (Sharp Head). In the south, the citadel ends in a few natural stone ribs, which were reinforced by a rampart, of which almost nothing is left. Roman practice was to demolish the walls of conquered cities. One year before the siege of Promona, Octavian had led the campaign
App. III. 25. Veith 1914, 69-76; Čače 1979, 103-104; Bilić-Dujmušić 2004, 494-501. Bilić-Dujmušić 2004, 477 Bilić-Dujmušić 2004, 461-463. Orišnica plateau, with the citadel tower on the Velika Orišnica hill. 


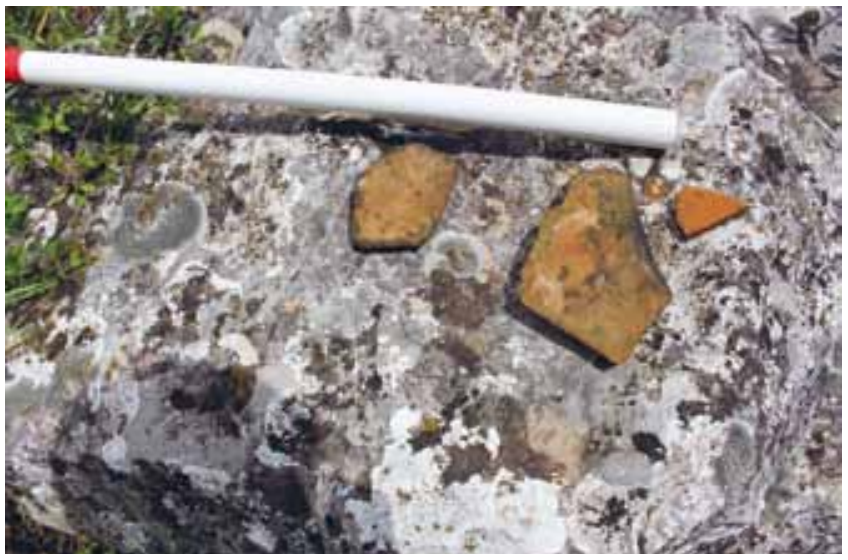

FIGURE 6. Fragments of ceramics found on the surface (photo by Ž. Miletić).

against the lapodes, and, according to Appian (Illyr, 21), "had completely destroyed Metulum, and no trace of wall remained, though it was the largest town in these areas". We can assume that the same fate befell the Promona citadel, as Strabo (7.5.5) states that Augustus burned the poleis of Salona, Promona and Ninia, as well as the old and new Sinotion.

\section{Contravallation}

Recent research has revealed the remains of Octavian contraval-

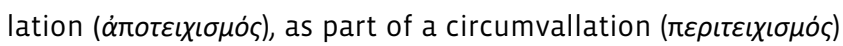
which Appian says was designed to have a length of 40 stadia (about 7 kilometres) with the aim of encircling the town and the two hills still held by the enemies (Appian's Illyr. 25; 26) (Fig. 9). Due to the rapid development of the military situation, a fortification line that encircled Promona was not completed when Testimus's army, arriving to help Versus, was thrown into the mountains (Svilaja and Moseć, undoubtedly), nor five days later, when Promona was conquered. As the battle with Testimus

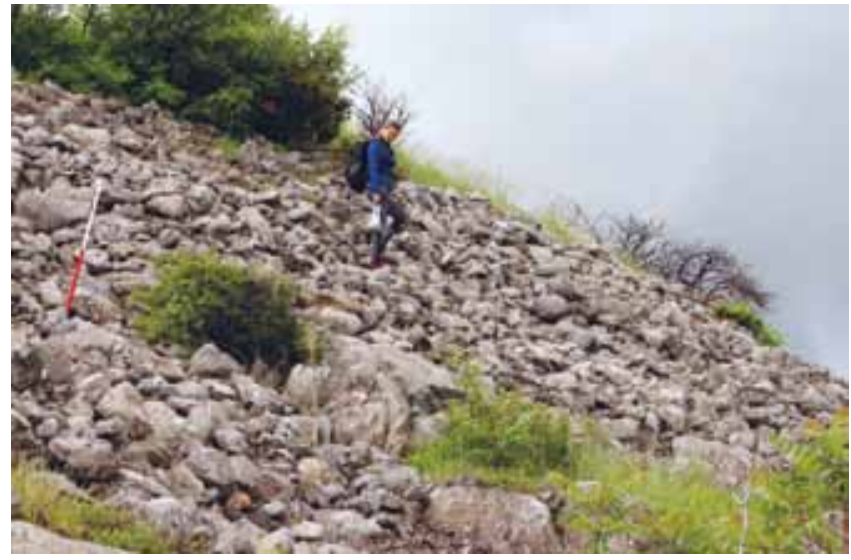

FIGURE 7. Remains of the collapsed ramparts on the north and northeast sides between Velika Orišnica and the Petrovac hill (photo by Ž. Miletić).

proved, the siege fortifications had one more purpose: to protect the legions from external enemies - that is, from the intrusion of Dalmatae from behind.

Octavian's contravallation (vallus contra hostes), with integrated siege camps of various dimensions, was recognized by analysis of aerial photographs in combination with the results of field surveying. Artificial structural elements such as embankments (vallum) and trenches (fossa) have been identified (Fig 10). The caput of this unfinished contravallation was the siege camp we discovered in the position of Glavičine, in the village of Parčić, from which the fortification line was made in a near straight line along a low ridge, about 1 kilometre long and 200 to 600 metres wide, to the northwest corner of Petrovo polje, in the direction of Orišnica-Promona (Fig. 11). Today it is in the area of the villages of Parčić and Miočić. The ridge is crossed by streams and has naturally the best defensive position on the Field, protected from enemy penetration from the slopes of the Svilaja mountain in the hinterland. If a second arm of contraval-

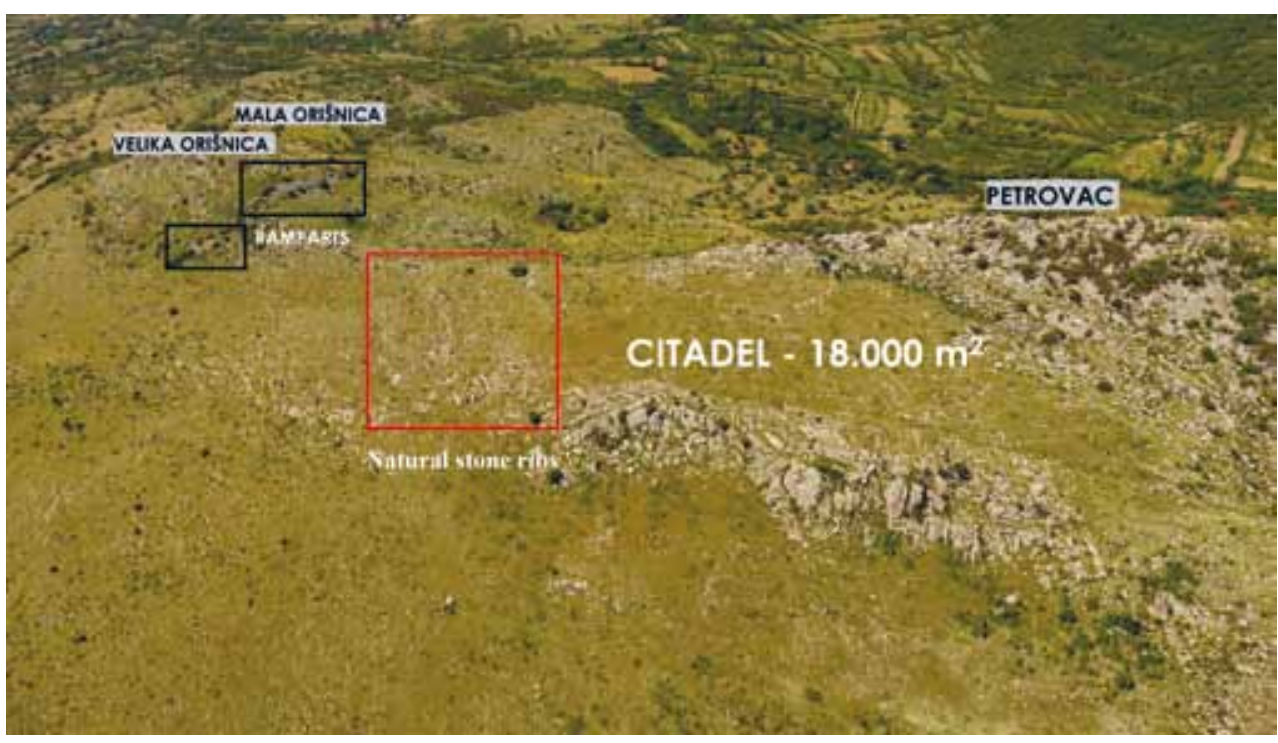

FIGURE 8. The citadel encloses an area of approximately 18,000 square metres. In the south, to wards the hill of Orišnica, the citadel ends with several natural stone ribs, which were reinforced by a rampart. The long east and west sides of the citadel end in high, steep cliffs (made by $S$. Bekavac, Ž. Miletić). 
FIGURE 9. Remains of Octavian's unfinished contravallation, starting at the siege camp of Parčić (made by S. Bekavac, Ž. Miletić).

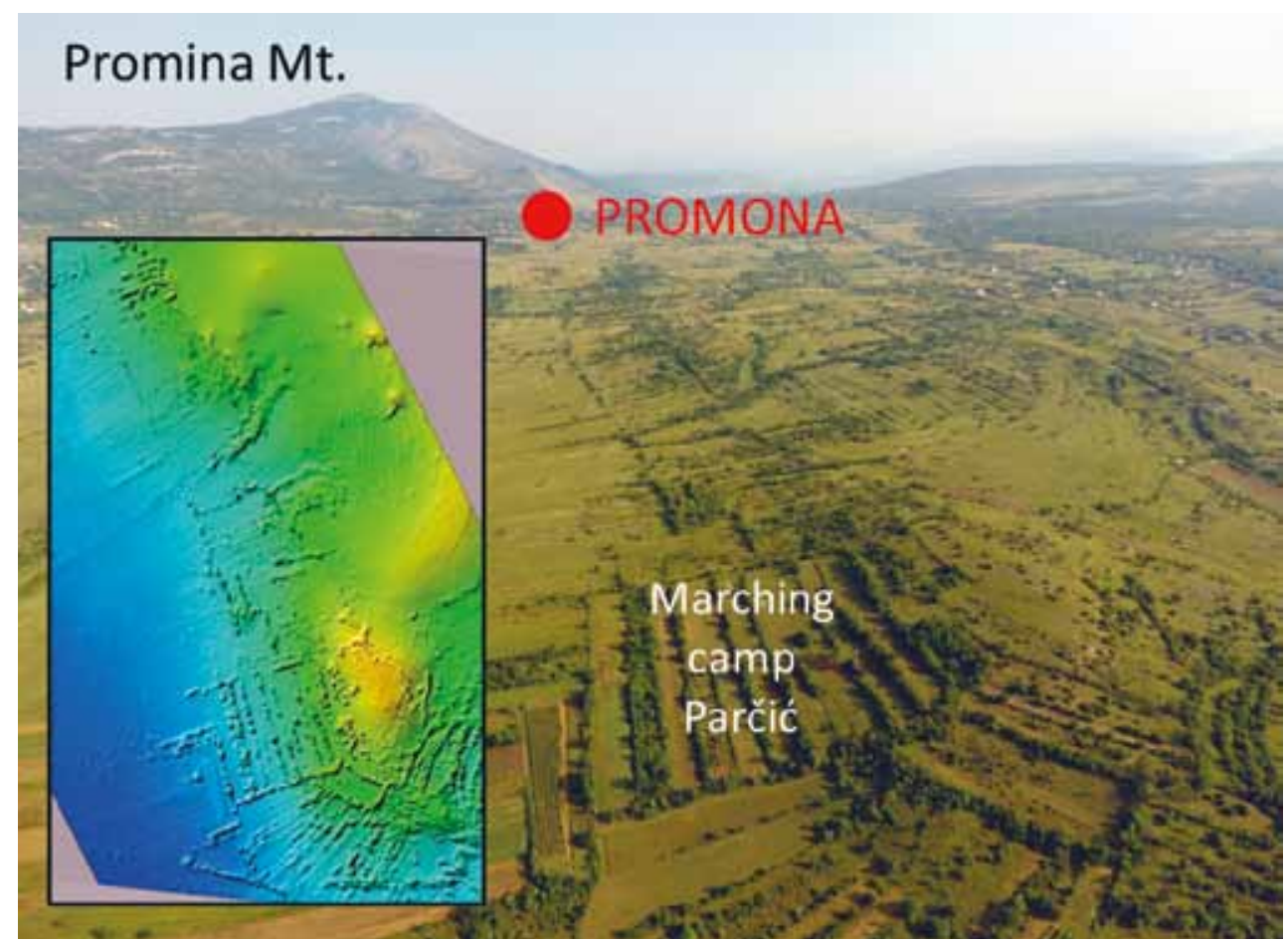

FIGURE 10. Contravallation with siege camps, with artificial structural elements such as embankments (vallum) and trenches (fossa) on the photo (made by S. Bekavac, Ž. Miletić).

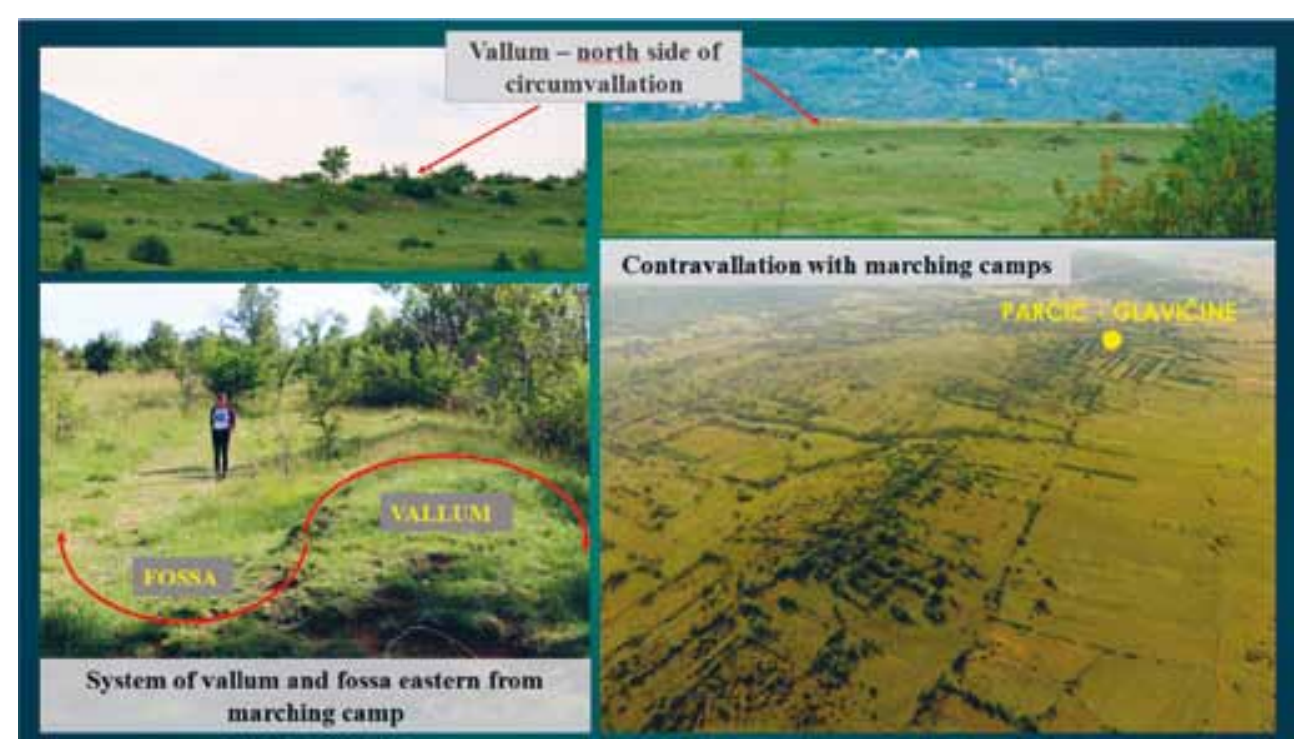

lation had been accomplished, it would probably have been laid from the camp at Parčić, and directed westward to the village of Siveric on the slopes of the Promina mountain. At the very beginning of the siege, the Romans seized the sentry posts on the heights of the Promina mountain with direct commando attacks, and this newly established line, along with two arms of the siege wall in the field, completely enclosed the Delmatae in the town of Promona. The total distance from the camp at Glavičine, along the assumed lines of these two arms to their ends on the slopes of the mountain, is approximately 7 kilometres, which is in agreement with Appian's data.
The relief layout of the Glavičine camp has a distinctive square shape with rounded corners (Fig. 12). The cross-section of the layers of the southern vallum of the camp showed a different stratification than those inside and outside the camp. The stone upper zone of the embankment is about 6 metres wide, sufficient to serve as a platform for a palisade at the top of the vallum, with a walkway for the soldiers on the inside of the camp. Defence was reinforced by ditches, visible on the north side of the camp outside the vallum. 


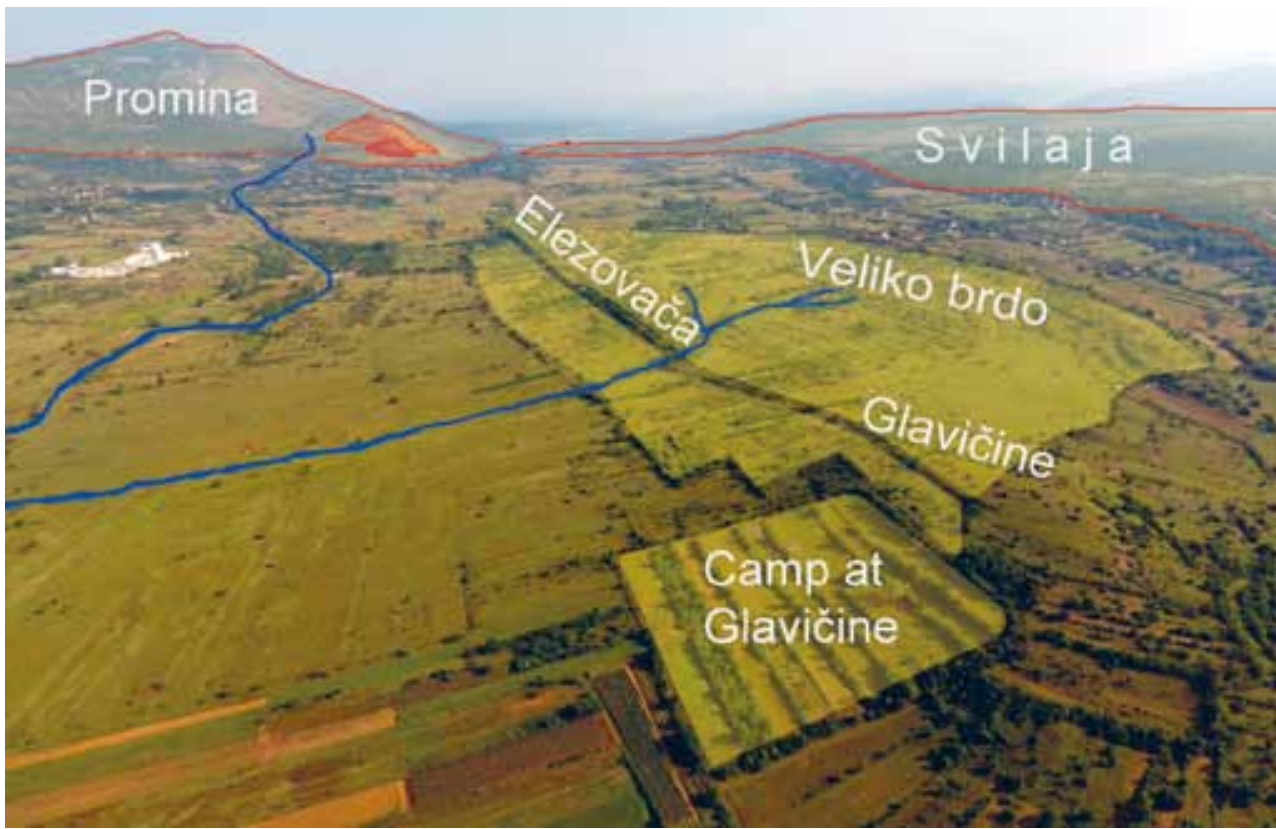

FIGURE 11. The fortification line was made in a near-straight line along a low ridge, about 1 kilometre long and 200 to 600 metres wide, to the northwest corner of Petrovo polje, in the direction of Orišnica-Promona (made by S. Bekavac, Ž. Miletić).

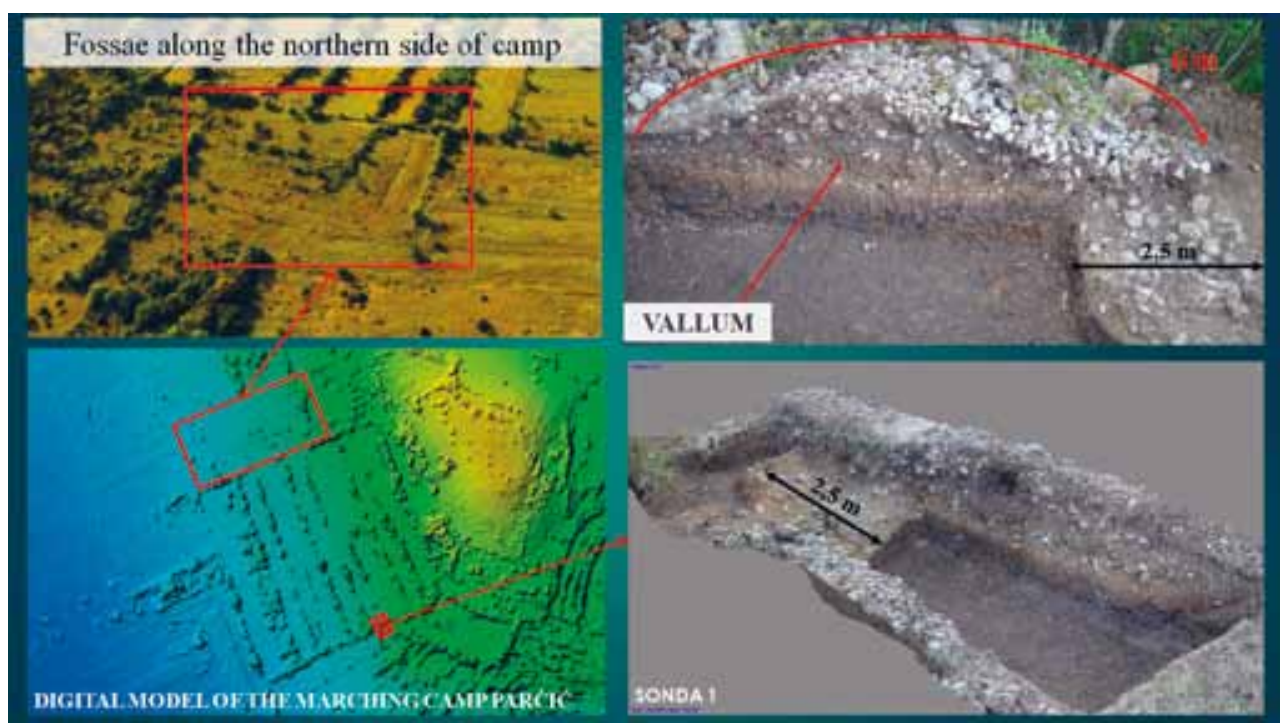

FIGURE 12. Artificial structural elements (vallum and fossa) along the northern and southern sides of the siege camp at Parčić (made by S. Bekavac, Ž. Miletić).
War with the Delmatae was a continuation of the Octavian Campaign during which the area of the lapodes and the town of Siscia, in Pannonia, were conquered the previous year. $4^{0}$ The siege of Promona was part of a large-scale military operation, so we speculate that the number of Roman soldiers was at least 30.000.41 If this was the case, it was necessary to build siege camps with a total area of more than one square kilometre for the accommodation of some eight legions. The artificial squares recognized to date on the slopes of the elongated ridge have approximately half of that size.

\section{Roads}

After the rejection of Testimus's reinforcements and the breakup of Versus's army in Promona, Octavian continued his action towards the southeast of Petrovo polje, which is part of the territory of the Delmatian polis of Sinotion (Fig. 13; Fig. 17). ${ }^{42} \mathrm{He}$ used paths that had already been trodden. It is essential for us to conclude from the aforementioned episode with Aulus Gabinius (Appian, Illyr. 12), which took place at the turn of 48 to $47 \mathrm{BC}$, there is already a transit route from northern Italy and $2005,446-448$ 


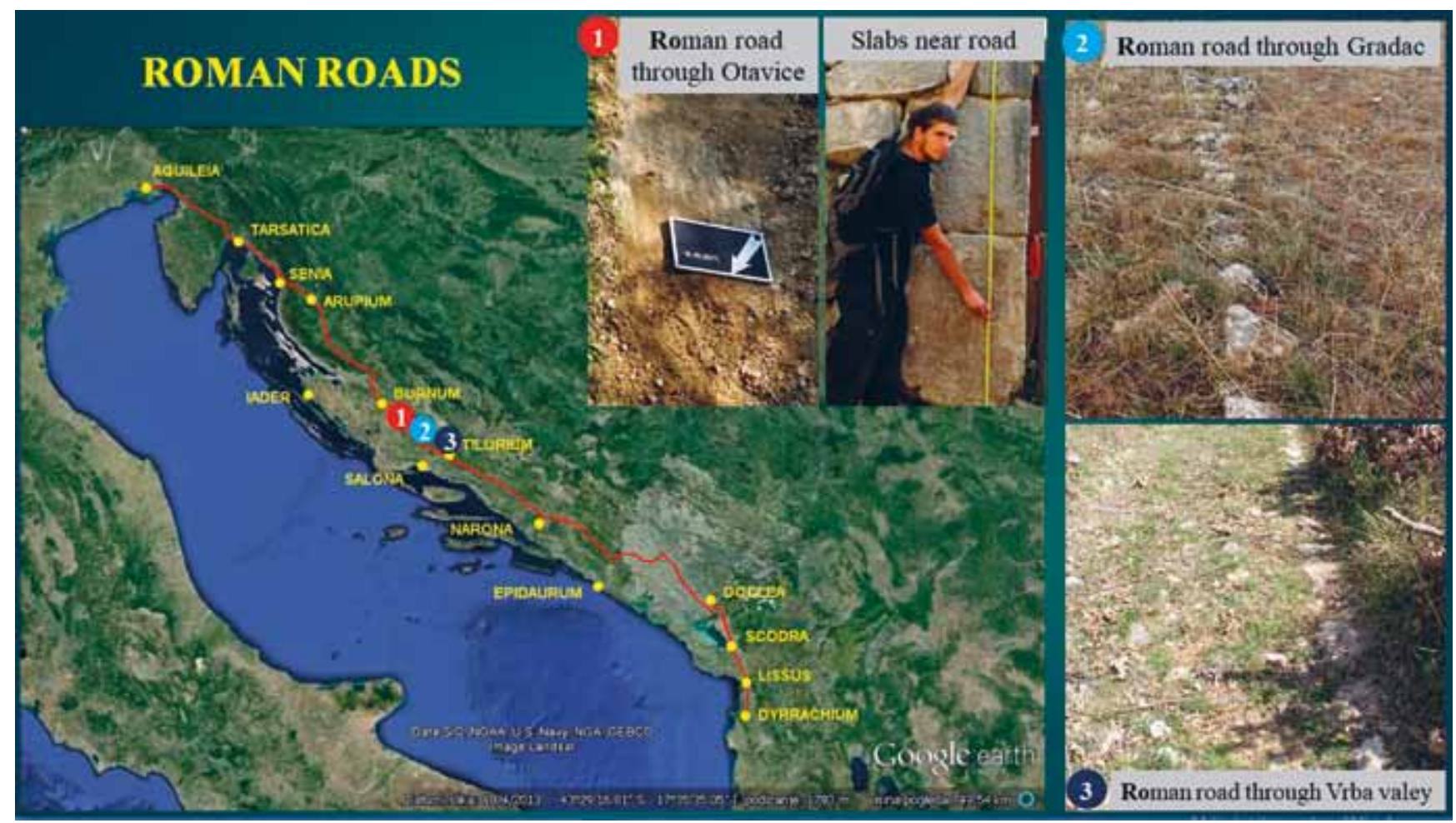

FIGURE 13. Remains of Roman roads through Otavice, Gradac and the Vrba valley (made by S. Bekavac, Ž. Miletić).

northwest Illyricum to the Dalmatian territory. Therefore, we think that Octavian went from Siscia to Promona and Sinotion, through the newly-acquired territory of the lapodes, by one of two possible communication lines. Above one of them the later road ad imum montem Ditionum Ulcirum and its continuation in the Claudius era from the Ulcirus mountain, through the valley of the River Una to Siscia, was laid. ${ }^{43}$ Above the second route, the via munita Aquileia - Dyrrachium was built later. One segment of it ran past Promona, between the two mountains (Svilaja and Promina), entered the Petrovo polje along the contravallation built by Octavian, and then headed towards Salona. ${ }^{44}$ Part of the route we have defined and documented on the southern slopes of the mountain of Svilaja, and it is probably related to the Appian (IIlyr. 27) statement about Testimus, who, seeing the difficult tactical position of his army, which had failed to help Versus in Promona, renounced the defence of Sinotion, ordering that the soldiers should not use roads but rather scatter across the mountains. The recorded strata of the road and the remains of the unexcavated bridge across a ravine are probably from the reign of Augustus or Tiberius, but they were preceded by the path used by Octavian.

43 Bojanovski 1974, 203-220, map IV; CIL XVII/4-2, 160-167, milestones from the road a Burno Sisciam

$44 \quad$ Miletić 1993, 134-136; Glavaš 2015, 131-134. In this segment of the road Tabula Peutingeriana depicts the following information: Burno - XVI-Promona - VIII - Magno.

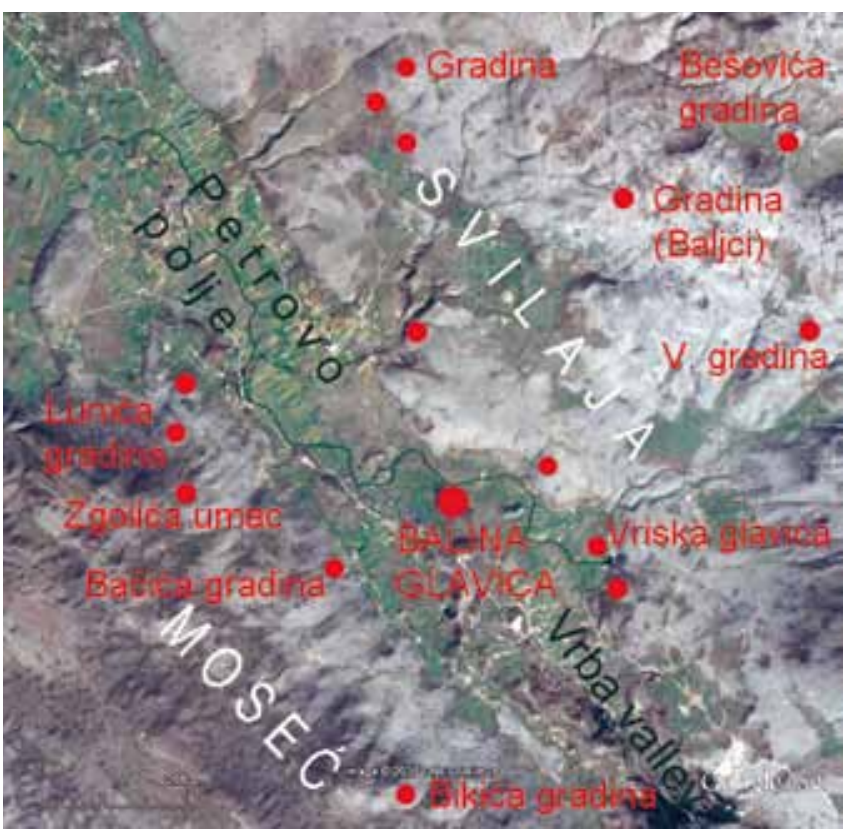

FIGURE 14. The hill forts on the edges of the eastern half of Petrovo polje (made by S. Bekavac, Ž. Miletić).

\section{Siege camp in Gradac, in the territory of Sinotion}

We want to point out that the two cities New and Old Sinotion, mentioned by Strabo (7.5.5) and burned by Augustus, probably owned the same territory; only the location of the central settlement changed. So the area of either Sinotion covered the hillforts on the territory of the modern villages of Umljanović, Ružić, Gradac and Baljci, on the edges of the eastern half of Petrovo 


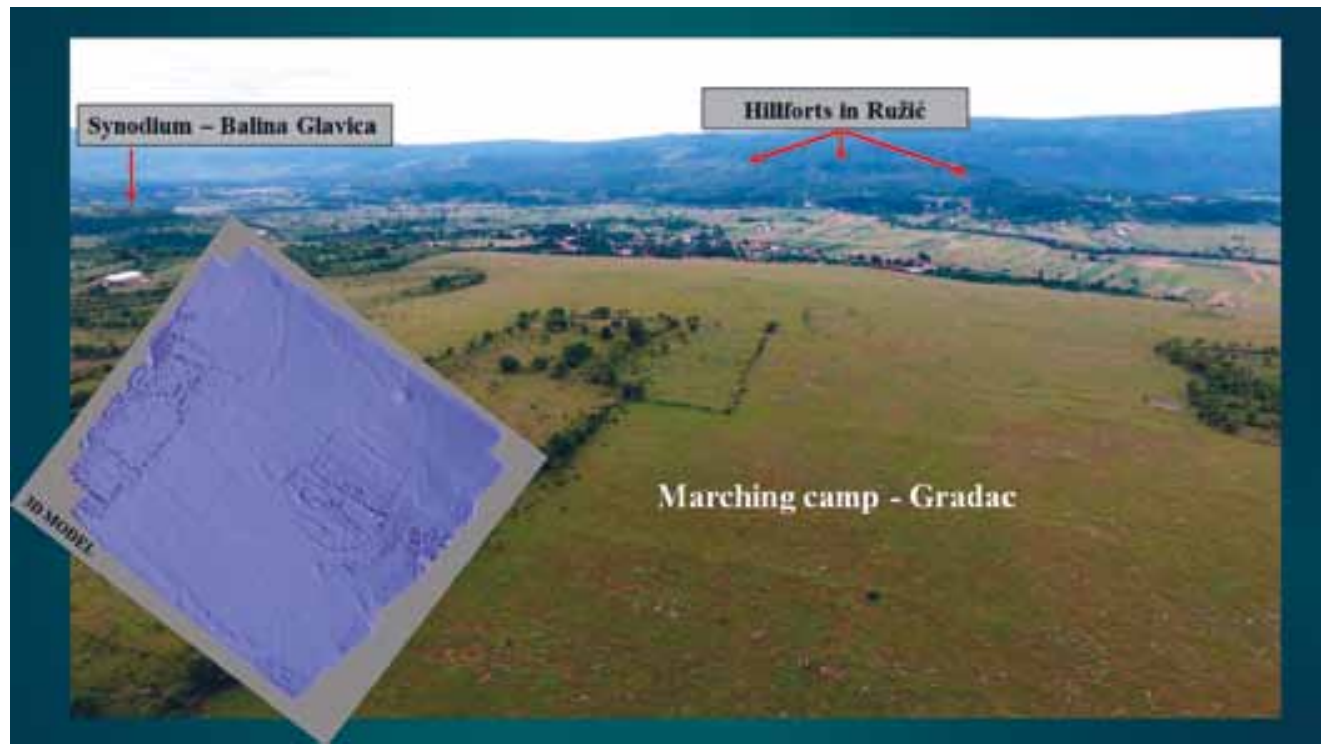

FIGURE 15. The location of the siege camp in Gradac (made by S. Bekavac, Ž Miletić).

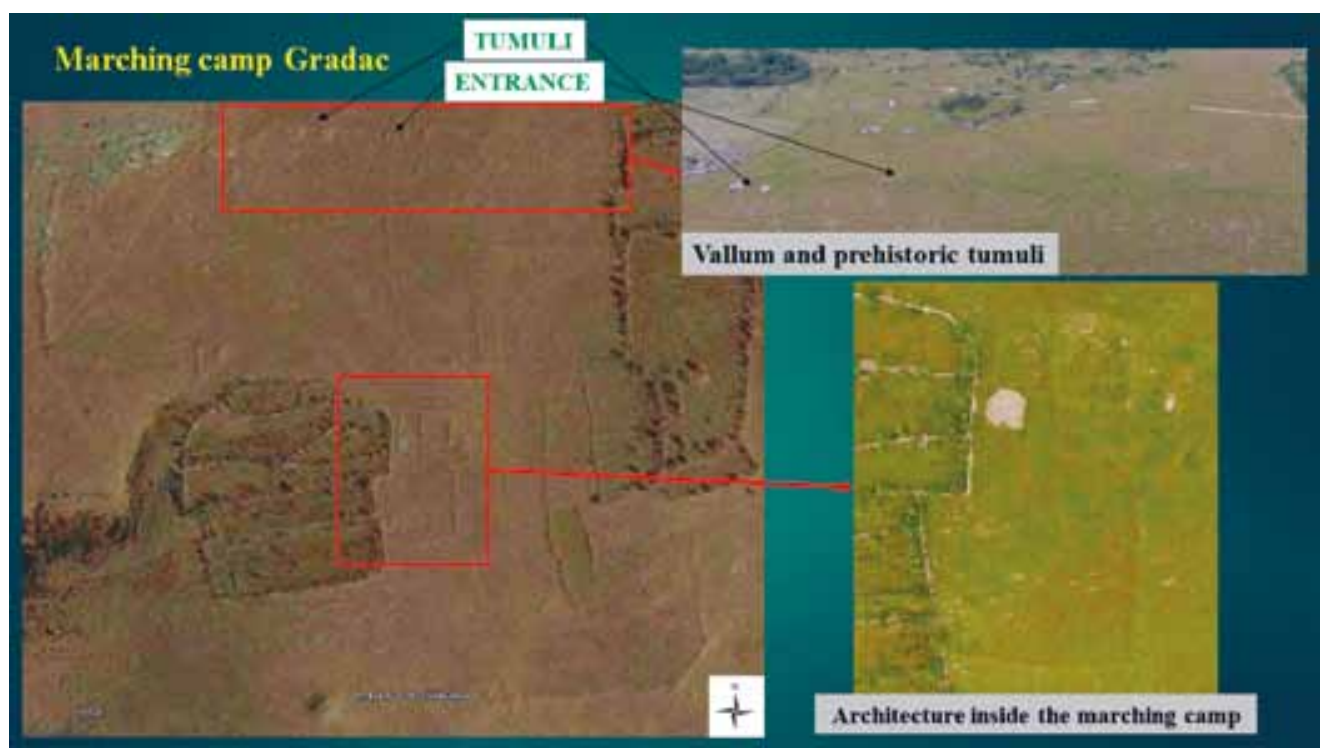

FIGURE 16. Architecture inside the siege camp in Gradac with vallum and prehistoric tumuli used as a sort of watchtower or a defence mound (made by $\mathrm{S}$. Bekavac, Ž. Miletić). polje. The seat of the territory of Old Sinotion may be on the joint hillforts in the village of Ružić or on the hillforts above Gradac, on the slopes of the Svilaja mountain. We consider New Sinotion to be a striking oppidum on the eastern tip of the triangularshaped Petrovo polje on the hill of Balijina Glavica (alternative toponym Balina Glavica), at the foot of which the Roman municipium Magnum was later constituted (Fig. 14).45 The position of New Sinotion corresponds perfectly to the spatial definition by Appian (IIlyr. 25; 27); it was, in fact, on the edge of a large forest where a deep and elongated gorge begins, in which Caesar's legate Aulus Gabinius was ambushed by Delmatae during the Civil War. In addition to the camps in Glavičine, another was built for the siege of Promona and Sinotion on a flat karst plateau on the last slopes of Mount Svilaja above the village of Gradac, on the route of the aforementioned road (Fig. 15). Its dimensions and shape we have determined by analysis of aerial images and through field survey. The camp completely covered this plateau, incorporating a few prehistoric tumuli, probably as a sort of watchtower or a defence mound. It is easy to spot the perimetral vallus contra hostes, which was interrupted by outer gates reinforced by several hummocks, and the interior space of the camp was divided by walls into smaller squares (Fig. 16). Recently, this ground has been deep-ripped with a heavy plough, so the structures are damaged, but due to this we know that, under the thin layer of soil, there are firm stones, which is why the soldiers did not dig trenches in front of the perimeter. 
FIGURE 17. The path of advance of Octavian's army from Promona, through Sinotion to Setovia (made by S. Bekavac, Ž. Miletić).

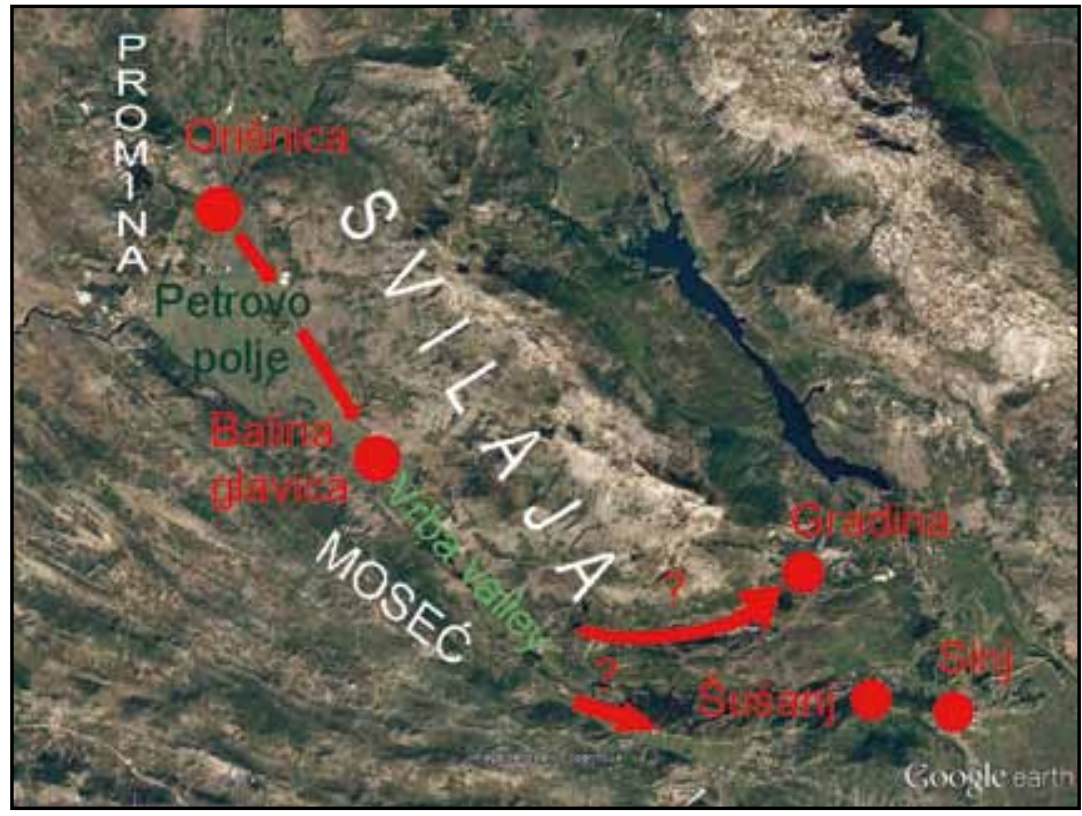

\section{Setovia}

Appian, ${ }^{46}$ writing about the further course of Octavian's advancement, points out that he secured the sides and cut the forests, thereby avoiding the aforementioned catastrophic error of Gabinius in the deep valley of the Vrba streamlet. Octavian burned down a number of Dalmatian settlements along the Roman march route east of the polis of Sinotion, which today we recognize as the hill forts from the Petrovo polje to the Mućko polje. Somewhere at the eastern end of that area was Setovia (Fig. 17). During the winter months, the Romans besieged the remaining army of the Delmatae and their allies there, as the last act of Octavian's military campaign in the region during 34 and $33 \mathrm{BC} .{ }^{47}$ As we did not conduct field research here, we will just note that there are numerous suggestions for the location of this stronghold.$^{48}$ One plausible proposal for the placement of Setovia is the Šušanj hill near the village of Lučani, where prehistoric artefacts have been found, and the remains of the ramparts are still visible. This oppidum is probably a central settlement of the community to which also belonged the hillfort of Zasutina, near Vidići, and the one near the hamlet of Đipalo.49 The finding of an inscription mentioning Osinium, from which the name of the modern town Sinj has developed, led to rejection of the earlier equation of Sinj with Setovia. ${ }^{50}$ Despite this, Periša recently practically restored Veith's equation. Drywall structures in the Turjački podi (on the south-west edge of Sinjsko polje), previously considered to be prehistoric defensive ramparts, he sees in exactly the opposite function, as part of the structures of the Roman outer siege ring around Setovia (route: Visoka hill, Turjački podi, Gardun, Svalinova gradina, Strmendolac, Ruda,
Cetina and Karakašica rivers, Šušanj hill in Lučani), which he locates beneath the present-day town of Sinj. ${ }^{51}$ The circumference of this hypothetical annular structure is nearly 40 kilometres, so it raises the question of its function. Only the exploration of individual objects - and, in particular, the determination of the date of their construction - will offer arguments for or against the hypothesis. We note that one of the possible locations of Setovia is an unexplored large hillfort, Gradina, in the village of Zelovo, on the eastern slopes of the Svilaja mountain.

On the basis of spatial field research compared with the description of Octavian's Campaign by Appian and Dio Cassius, we conclude that the central oppidum of the Dalmatian polis of Promona integrated three areas (Mala Orišnica plateau, karstic lea to the southeast, and Velika Orišnica hill). On the Petrovac hill we have located the citadel (acropolis) of Promona. Our recent field research has revealed the remains of circumvallation around that polis, with integrated siege camps. The caput of un finished fortifications was a siege camp that we have discovered in the position of Glavičine in the village of Parčić. Another one was built for the siege of Promona and Sinotion (oppidum at the eastern tip of the triangular-shaped Petrovo polje, on the hill of Balijina Glavica) on a flat karst plateau on the last slopes of Mount Svilaja, above the village of Gradac. Octavian's campaign ended with the siege of Setovia during the winter of $34-33 \mathrm{BC}$. We assume that this oppidum should be connected with some of the hillforts between Mount Moseć, Mount Svilaja and Sinjsko polje.
App. III. 27

Bilić-Dujmušić 2004, 519-526; Šašel Kos 2005, 448-449

Periša 2015, 265-267

Gunjača 1937, 33-38; Milošević 1984, 285

Veith 1914, 98-104; 111-112; Jadrijević 1940, 157-159. 


\section{BIBLIOGRAPHY}

Alačević 1878 - J. Alačević, II municipio Magnum ed altri luoghi lungo la via Romana da Salona a Burnum, Bullettino di archeologia e storia dalmata 1/6 - 9, $1878,90-144$

Bilić-Dujmušić 2000 - S. Bilić-Dujmušić, Ratne operacije u provinciji Ilirik 49. - 47. pr. Kr., unpublished MA thesis, Sveučilište u Zadru, 2000.

Bilić-Dujmušić 2004 - S. Bilić-Dujmušić, Oktavijanova kampanja protiv Delmata 34. - 33.god. pr. Kr., unpublished PhD thesis, Sveučilište u Zadru, 2004

Bojanovski 1974 - I. Bojanovski, Dolabelin sistem cesta u rimskoj provinciji Dalmaciji, Akademija nauka i umjetnosti Bosne i Hercegovine, Sarajevo, 1974

Britvić 1971 - J. Britvić, Neka topografsko-povijesna pitanja s teritorije Delmata Vjesnik za arheologiju i historiju dalmatinsku 65-67, 1971, 27-37.

Broughton 1951 - T. R. S. Broughton, The Magistrates of the Roman Republic 509 B.C.-100 B.C., 1, Philological monographs 15, American Philological Association, 1951

Bunijevac 2009 - H. Bunijevac, Željeznica kao preduvjet gospodarskog razvoja Like, in Holjevac, Ž. (ed.), Identitet Like: Korijeni i razvitak 1, Institut društvenih znanosti Ivo Pilar - Područni centar Gospić, 2009, 542-569.

Campedelli, Dubbini, Monica 2017 - A. Campedelli, M. Dubbini, M. Monica, Geo-archaeological study of the territory of Burnum's Roman Site (Croatia) Through LANDSAT multi-temporal satellite images and high resolution Geoeye, Archeologia e Calcolatori 28/2, 2017, 277-290

Chiabà 2017 - M. Chiabà, Epigrafia e politica dall'Urbe alla provincial: il caso dell'iscrizione trionfale di Gaio SempronioTuditani (cos. 129 a.C.), in Segenni S. Bellomo M. (eds.), Epigrafia e politica. II contributo della documentazione epigrafica allo studio delle dinamiche politich en el mondo romano 4, Ledizioni, 2017, 171-195

Čače 1979 - S. Čače, Prilozi proučavanju političkog uređenja naroda sjeverozapadnog Ilirika, Radovi. Razdio društvenih znanosti, 18/8, 1979, 43-125.

Čače 1991 - S. Čače, Rim, Liburnija i istočni Jadran u 2.st. pr. n. e., Diadora 13, 1991, 55-76.

Čače 1993 - S. Čače, Prilozi povijesti Liburnije u 1. stoljeću prije Krista, Radovi Zavoda za povijesne znanosti HAZU u Zadru 35, 1995, 1-35.

Dzino 2005 - D. Dzino, Illyrian policy of Rome in the late Republic and early Principate, unpublished PhD thesis, University of Adelaide, 2005.

Dzino 2005 - D. Dzino, Asinius Pollio in Dalmatia: What happened in Salona 39 BC?, Klio 93, 2011, 158-166

Glavaš 2012 - I. Glavaš, On the municipality of Magnum,Opuscula archaeolog ica 36, 2012, 93-103.

Glavaš 2015 - I. Glavaš, Vojno značenje cesta u rimskoj provinciji Dalmaciji za principata, unpublished Phd thesis, Sveučilište u Zadru, 2015.

Gunjača 1937 - S. Gunjača, Topografska pitanja na teritoriji Cetinske županije s ekskursima o ubikaciji Setovije i Tiluriuma, Split 1937.

Jadrijević 1940 - A. Jadrijević, Novi rimski natpis s grada Sinja, Vjesnik za arheologiju I historiju dalmatinsku 51, 1940, 157-158.

Lutton 2012 - S. Lutton, Asinius Pollio, unpublished PhD thesis, University of Western Australia, 2012

Marasco 1997 - G. Marasco, Aulo Gabinio e l'Illiria al tempo di Cesare, Latomus $56 / 2,1997,307-326$

Miletić 1993 - Ž. Miletić, Rimske ceste izmeđujadera, Burnuma i Salone, Radovi Filozofskog fakulteta u Zadru, 32/19, 1993, 117-150.
Miletić 2006 - Ž. Miletić, Roman Roads along the Eastern Coast: State of Research, in Čače, S., Kurilić, A., Tassaux, F. (eds.), Les routes de l'Adriatique antique. Géographie et économie, Actes de la Table ronde du 18 au 22 septembre 2001 (Zadar) / Putovi antičkog Jadrana : geografija i gospodarstvo : radovi s Okruglog stola održanog u Zadru od 18. do 22. rujna 2001., Institut Ausonius, Sveučilište u Zadru, 2006, 125-136

Miletić 2020 - Ž. Miletić, Rimska infrastruktura južne Liburnije, Polački kraj u prošlosti i sadašnjosti. Zbornik radova sa znanstvenog skupa Polački kraj u prošlosti i sadašnjosti održanoga u Ražnjevića dvorima u Polači 7. svibnja 2016., Ogranak Matice Hrvatske u Zadru, 2020, 21-41.

Milivojević 2017 - F. Milivojević, Cezarov llirik, unpublished PhD thesis, Sveučilište u Zadru, 2017.

Milošević 2017 - A. Milošević, Srednjovjekovna nekropola u "Barama" u Lučanima kod Sinja, Starohrvtaska prosvjeta 14, 1984, 285-304.

Mirnik 2009 - I. Mirnik, Nacrt numizmatičke topografije Like, in Holjevac, Ž. (ed.), Identitet Like: Korijeni i razvitak 1, Institut društvenih znanosti Ivo Pilar Područni centar Gospić, 2009, 442-492.

Morgan 1971 - M. G. Morgan, "Lucius Cotta and Metellus". Roman Campaigns in Illyria during the late second century B.C., Athenaeum 49, 1971, 271-301.

Periša 2008 - D. Periša, Je li delmatsko područje presjekao rimski limes?, Archaeologia Adriatica, 2/2, 507-517.

Periša 2015-D. Periša, Arheološka svjedočanstva o Rimsko-delmatskimratovima, unpublished PhD thesis, Sveučilište u Zadru, 2015.

Rašković 2001 - D. Rašković, Antička Promona, in M. Lazić (ed.), Vestigatio vetustatis Aleksandrini Cermanović Kuzmanović od prijatelja, saradnika i učenika, Centar za arheološka istraživanja 20, Sveučilište u Beogradu, 2001, 391-409.

Šašel Kos 1986 - M. Šašel Kos, Zgodovinska pod oba prostora med Akvilejo, Jadranom in Sirmijem pri Kasiju Dionu in Herodijanu, Inštitut za arheologijo ZRC SAZU, 1986.

Šašel Kos 2005 - M. Šašel Kos, Appian and the Illyricum, Inštitut za arheologijo ZRC SAZU, 2005

Šašel Kos 2013 - M. Šašel Kos, The Roman Conquest of Illyricum (Dalmatia and Pannonia) and the Problem of the Northeastern border of Italy, Studia Europaea Gnesnensia 7, 2013, 169-200.

Veith 1914 - G. Veith, Die Feldzüge des C. Iulius Caesar Octavianus in Illyrien in der Jahren 35 - $33 \mathrm{v}$. Chr., Schriften der Balkankommision, antiquarische Abtheilung 7, Kommission bei Alfred Hölder, k. u. k. Hof- und UniversitätsBuchhändler, Buchhändler der kaiserlichen Akademie der Wissenschaften, 1914 .

Vrkić 2017 - Š. Vrkić, Toward archaeological topography of the village of Radučić near Knin, Diadora 31, 2017, 197-222.

Wilkes 1969 - J. J. Wilkes, Dalmatia, History of the provinces of the Roman Empire, Routledge \& Kegan Paul, 1969

Zaninović 1968 - M. Zaninović, Burnum. Castellum - municipium, Diadora 4 Zadar, 1968, 119-129.

Zaninović 1988 - M. Zaninović, Liburnia militaris, Opuscula archaeologica 13, $1988,43-67$.

Zaninović 1992 - M. Zaninović, Od Ninije do Promone, in Čečuk b. (ed.), Arheološka istraživanja u Kninu i Kninskoj krajini. Znanstveni skup Knin 13.-15. X. 1987, Izdanja HAD-a 15, Hrvatsko arheološko društvo, 1992, 33-40. 